\title{
MALING (DRAMA TARLING) PADA SISWA-SISWA SMA SE-KABUPATEN INDRAMAYU
}

\author{
Saroni $^{1}$, Nana Triana Winata ${ }^{2}$ \\ ${ }^{1}$ Universitas wiralodra, inorasironi@yahoo.co.id \\ ${ }^{2}$ Universitas wiralodra, nanawinata26@gmail.com
}

\begin{abstract}
ABSTRAK
Seni pertunjukan tarling di Indramayu merupakan pertunjukan teater tradisional. Kondisi ideal yang diharapkan adalah seni pertunjukan tarling sebagai identitas daerah Indramayu tetap lestari, tetapi ternyata semakin pudar dan tak bertenaga. Dengan demikian, perlu adanya revitalisasi budaya lokal melalui pemberdayaan generasi muda. Upaya revitalisasi seni pertunjukan tarling merupakan upaya pemertahanan eksistensi kesenian tradisional tarling kepada generasi muda. Revitalisasi perlu segera dilakukan karena seni pertunjukan tarling telah hampir punah karena tidak menjadi sebuah industri yang berasal dari kreativitas senimannya.

Berdasarkan permasalahan-permasalahan di atas, peneliti merancang penelitian sebagai berikut: 1) menyebarkan angket pada siswa-siswa SMA di Kabupaten Indramayu terkait dengan minat drama, 2) melakukan pelatihan MALING (Drama Tarling) bagi siswa-siswa SMA di Kabupaten Indramayu, 2) untuk menunjang pelatihan MALING (Drama Tarling) maka, peneliti melakukan kerja sama dengan Dinas Kebudayaan dan Pariwisata untuk memanfaatkan alat-alat gamelan tarling sebagai penunjang dalam melakukan penelitian, 4) untuk membantu program kerja Dinas Kebudayaan dan Pariwisata Kabupaten Indramayu yaitu mengadakan malam pementasan drama di taman kota Indramayu, maka tim merancang sebuah pementasan per kelompok untuk dapat dipentaskan setiap minggunya, 5) menyebarkan angket pada siswa-siswa SMA di Kabupaten Indramayu yang mengikuti pelatihan MALING (Drama Tarling) untuk mengetahui perkembangan minat drama.

Hasil penelitian melalui angket awal yang disebar menunjukan bahwa aspek pengetahuan dengan nilai 331 kategori baik, aspek minat dengan nilai 297 kategori baik, aspek apresiasi dengan nilai 307 kategori baik, aspek sikap dengan nilai 291 kategori baik, dan yang terakhir aspek harapan dengan nilai 286 kategori baik. Jika dibandingkan antara angket awal dan akhir, adanya peningkatan minat dan keterampilan siswa dalam bermain drama. Pada aspek pengetahuan dengan nilai 425 kategori sangat baik, aspek minat dengan nilai 407 kategori sangat baik, aspek apresiasi dengan nilai 419 kategori sangat baik, aspek sikap dengan nilai 412 kategori sangat baik, dan yang terakhir aspek harapan dengan nilai 434 kategori sangat baik. Hal ini menunjukan bahwa dengan adanya pelatihan MALING dapat membantu dalam meningkatkan minat dan keterampilan siswa dalam bermain drama.

Oleh karena itu pelatihan MALING (Drama Tarling) perlu direkomendasikan dan diharapkan tetap berlanjut untuk kelestarian seni budaya Indramayu. Kegiatan ini sangat efektif dalam menumbuhkan minat siswa-siswa/generasi baru dan eksistensi kesenian tradisional tarling kepada generasi muda dalam bermain drama tarling.
\end{abstract}

Kata Kunci : Drama, Tarling, Siswa SMA, Indramayu. 
How to Cite: Saroni \& Nana, T. Winata. (2020). "MALING (Drama Tarling) pada SiswaSiswa SMA Se-Kabupaten Indramayu." Bahtera Indonesia: Jurnal Penelitian Pendidikan Bahasa dan Sastra Indonesia, Vol. 5, No. 2, 176-191.

DOI: https://doi.org/10.31943/bi.v5i2.94

\section{PENDAHULUAN}

\section{Latar Belakang Masalah}

Seni pertunjukan tarling di Indramayu seperti pertunjukan lainnya yang berkembang di Jawa seperti ketoprak, ludruk, dan lenong betawi merupakan teater tradisional. Hal-hal yang umumnya melekat pada teater tradisional ialah menceritakan cerita tradisional, penggarapannya secara tradisional, pelakon sudah tua-tua karena tidak ada regenerasi juga sangat kental melekat pada eksistensi tarling di Indramayu. Oleh karena itulah yang menyebabkan seni pertunjukan tarling semakin hari terlupakan di masyarakat Indramayu. Padahal bagaimanapun seni pertunjukan Tarling memiliki fungsi kebermanfaatan (useful). Mengingat fungsi kebermanfaatan, perlu upaya pemertahanan terhadap keberadaan seni pertunjukan tarling.

Seperti dikemukakan di atas, kondisi ideal yang diharapkan adalah kelestarian seni pertunjukan tarling sebagai identitas daerah Indramayu tetapi ternyata semakin pudar dan tak bertenaga. Seni pertunjukan tarling merupakan salah satu bentuk kesenian yang terpinggirkan dalam masyarakat kota yang cenderung hedonis. Keberadaannya seperti pepatah yang mengatakan "Hidup segan mati tak mau." Beberapa faktor krusial seperti menceritakan cerita tradisional dan penggarapannya secara tradisional yang menyebabkan seni pertunjukan tarling hampir terlupakan di masyarakat Indramayu.

Hasil observasi dan wawancara yang dilakukan oleh peneliti kepada Kepala Dinas Kebudayaan dan Pariwisata Kabupaten Indramayu, dapat disimpulkan sebagai berikut: 1) seperangkat gamelan (alat-alat musik tarling) tidak begitu dimanfaatkan dengan baik. Alat-alat tersebut seperti (gitar, kendang rampak, gong, kemling, dll) cenderung rusak karena jarang digunakan, 2) program malam pementasan di Kuliner Tjimanoek tidak berjalan dengan baik disetiap minggunya karena kekurangan pemain drama.

Selain melakukan observasi dan wawancara di Dinas Kebudayaan dan Pariwisata kabupaten Indramayu, peneliti juga melakukan observasi dan wawancara dengan guru-guru SMA di Kabupaten 
tersebut adalah sebagai berikut. 1) kegiatan bermain drama pada siswa SMA kurang mendapat apresiasi, 2) siswa tidak mengetahui tentang bagaimana cara bermain drama dengan baik dan mudah. Siswa hanya diberikan teknik yang kurang mendukung dalam kegiatan bermain drama, 3) kurangnya apresisasi tersebut membuat potensi siswa yang seharusnya sangat baik menjadi kurang, 4) siswa merasa bosan apabila belajar tentang keterampilan bermain drama.

Di sekolah-sekolah, naskah drama paling tidak dinikmati. Minat siswa dalam membaca karya sastra yang terbanyak adalah prosa, menyusul puisi, baru kemudian drama. Perbandingannya adalah: 6:3:1. Hal ini disebabkan karena menghayati naskah drama yang berupa dialog itu cukup sulit dan harus tekun. Penghayatan naskah drama lebih sulit daripada penghayatan naskah prosa atau puisi (Waluyo, 2002: 2). Keadaan yang demikian sudah tentu akan menimbulkan kesukaran bagi guru dan rasa tidak minat pelajar terhadap sastra yang dapat berakibat kepada proses pengajaran dan pembelajaran bahasa dan sastra menjadi tidak berkesan bagi siswa.

Dengan demikian, perlu adanya revitalisasi budaya lokal ini melalui pemberdayaan generasi muda. Upaya revitalisasi seni pertunjukan tarling merupakan upaya pemertahanan eksistensi muda. Revitalisasi perlu segera dilakukan karena seni pertunjukan tarling telah hampir punah karena tidak menjadi sebuah industri yang berasal dari kreativitas senimannya. Upaya revitalisasi seni pertunjukan tarling tersebut sudah menjadi salah satu program kerja Dinas Kebudayaan dan Pariwisata Kabupaten Indramayu.

\section{Rumusan Masalah}

Permasalahan utama penelitian ini adalah bagaimana rancangan pementasan drama tarling. Permasalahan tersebut dapat dirumuskan menjadi beberapa permasalahan sebagai berikut.

1) Bagaimanakah hasil observasi awal minat dan keterampilan siswa SMA dalam bermain drama?

2) Bagaimanakah melatih siswa SMA dalam mengembangkan minat dan keterampilan siswa dalam bermain drama melalui MALING (Drama Tarling)?

3) Bagaimanakah hasil observasi akhir minat dan keterampilan siswa SMA dalam bermain drama?

4) Bagaimanakah rancangan pementasan drama tarling siswa SMA di Kabupaten Indramayu

\section{Tujuan Penelitian}

Tujuan utama penelitian ini yakni untuk merancang pementasan melalui 
BAHTERA INDONESIA:

ISSN 2541-3252

Jurnal Penelitian Pendidikan Bahasa dan Sastra Indonesia

Vol. 5, No. 2 Sep. 2020

MALING (Drama Tarling) dengan bahasa jawa dalam pementasannya. Seperti

beberapa tahap. Tujuan penelitian ini untuk halnya diungkapkan Sulistijo, dkk, mengetahui: 2001:XIII-IX) dalam laras, suasana lagu,

1) hasil observasi awal minat dan tema drama, maupun bahasa pengantarnya keterampilan siswa SMA dalam yaitu bahasa Jawa dengan dialek Dermayonbermain drama?

Cerbon. Sedangkan menurut Soemardjo

2) hasil melatih siswa SMA dalam (2010: 158) tarling merupakan sastra lisan mengembangkan minat dan keterampilan siswa dalam bermain drama melalui MALING (Drama Tarling)?

Masyarakat Indramayu memberikan

3) hasil observasi akhir minat dan keterampilan siswa SMA dalam bermain drama?

4) rancangan pementasan drama tarling siswa SMA di Kabupaten Indramayu?

\section{LANDASAN TEORI}

\section{Seni Budaya Tarling}

Faruk dalam Kongres Bahasa dalam bentuk penuturan cerita legenda atau babad.

nama kesenian budaya dengan nama tarling dengan tujuan untuk mempertahankan kesan campurannya. Gitar dan suling adalah dua dunia yang berbeda, yang satu bersifat familiar dengan masyarakat setempat, sedangkan yang satu lagi mengandung konotasi asing atau Barat. Tarling adalah salah satu seni tradisi yang sangat khas dan terkenal dari daerah Cirebon dan Indramayu. Cirebon (2007) mengatakan bahwa Nama tarling diambil dari singkatan dua alat masyarakat Cirebon adalah masyarakat yang musik dominan, yaitu gitar (akustik) dan suling. Selain kedua instrumen ini, terdapat secara geokultural hidup di wilayah pula sejumlah perkusi, saron, kempul, dan perbatasan antara dua budaya, yaitu budaya Jawa dan budaya Sunda.Munculnya seni tarling di daerah Indramayu-Cirebon merupakan kekayaan kearifan budaya daerah.Kearifan budaya adalah fungsi dan nilai-nilai budaya yang menonjol dan memiliki kemampuan (daya pukau) yang luar biasa cerdas dalam memecahkan persoalan hidup (Santosa, 2011:7).Seni tarling bukan hanya menonjolkan pada kegiatan drama, namun juga pada lagu gong.Nama dan alat-alat musik yang dipergunakan sudah menunjukkan bahwa sesungguhnya tarling lebih condong pada seni tradisi dalam genre musik. Namun, jika disimak lebih jauh meskipun termasuk genre musik, tarling dapat dikatakan mengandung seni sastra. Hal itu dapat diketahui dari liriklirik lagu yang dibawakan dan dari drama yang disajikan selama pertujukan tarling berlangsung. Menurut (Saptono, 2013:23) Tarling merupakan kependekan dari kata 

gitar' dan 'suling', namun tarling juga Perkembangan selanjutnya menunjukkan

memliki filsafah 'yes wis mlatar, kudu eling'

Jika berbuat negative harus segera sadar dan bertobat.

Tarling juga merupakan genre sastra berbentuk puisi. Sebagaimana dikatakan oleh Riffatere dalam Suratno (2005) bahwa puisi adalah ekspresi tidak langsung yang menyatakan sesuatu dengan maksud lain. Ekspresi tidak langsung dalam puisi itu tampak dalam penggantian arti, penyimpangan arti, dan penciptaan arti. Penggantian arti terwujud dalam penggunaan metafora dan majasmajas lainnya. Penyimpangan arti disebabkan oleh ambiguitas atau makna ganda, dan kontradiksi. Penciptaan arti adanya konvensi kepuitisan yang berupa bentuk visual secara linguistik, seperti pembaitan, enjambement, persajakan, dan tipografis.Kategori ekspresi tidak langsung seperti yang telah dipaparkan tersebut terdapat pada teks tarling karena di dalam teks tarling mengandung peribahasa (ungkapan), wangsalan, parikan, ambiguitas, pengaturan bunyi akhir, tipografi, dan pengaturan bait.

Kesenian tarling diperkirakan lahir pada masa-masa perang kemerdekaan melawan pendudukan Jepang. Sepanjang malam semasa istirahat di sela-sela pertempuran mengalunlah lagu-lagu karawitan dengan instrumen gitar. Dua orang bermain gitar sebagai pengiring dan melodi serta yang lain sebagai penyanyi. perubahan dalam personal, misalnya instrumen ditambah dengan gong, gendang, dan tutukan (dua buah bonang berukuran besar dan kecilyang berfungsi sebagai pengatur irama). Lagu-lagu tarling awalnya berupa parikan dan wangsalan yang disambung-sambung oleh sinden menjadi sebuah rangkaian lagu. Lirik lagu itu berisi ungkapan hati penyanyi dalam melakonkan sebuah cerita dalam bentuk monolog. Pada waktu-waktu berikutnya cerita diungkapkan dalam bentuk dialog antara sinden dan pelaku tarling lainnya berdasarkan tema cerita yang disampaikan.

Berkaitan dengan tema, Kasim (2002) menyatakan bahwa tema-tema tentang romantika kehidupan rumah tangga menjadi tema-tema yang banyak yang diciptakan musisi tarling. Tarling dipertunjukan semata-mata mengandalkan improvisasi. Pada saat tampil, seniman tarling tidak berbekal teks lagu dan tidak ada cerita khusus yang akan disampaikan pada penonton. Namun, dalam penyampaiannya menjadi salah satu ciri khas tarling, pelaku tarling menggunakan dua gaya, yakni gaya parikan dan wangsalan, yang termasuk genre sastra, khususnya puisi. Sebagaimana diketahui parikan dan wangsalan adalah dua jenis puisi lama. Parikan adalah puisi berirama (murwakanti) yang terdiri atas dua atau empat baris. Jika larik dalam parikan terdiri atas dua baris disebut parikan tunggal, 
BAHTERA INDONESIA:

Jurnal Penelitian Pendidikan Bahasa dan Sastra Indonesia
ISSN 2541-3252

Vol. 5, No. 2 Sep. 2020

sedangkan yang empat baris disebut dengan sekolah-sekolah

SMA di Kabupaten parikan rangkap, misalnya apa kawat apa tali/lamun kawat disambung-sambung/apa Indramayu dan mengkonfirmasi mengenai niat apa bli/lamun niat aja tanggungtanggung/. Sedangkan wangsalan merupakan serangkaian kalimat yang merujuk pada satu makna. Dalam peristilahan modern, wangsalan disebut sebagai rhyming slang, mirip dengan tekateki atau badekan, misalnya ireng-ireng ning rerangkeng memiliki makna 'sawang', atau gelang alit mungging jriji yang bermakna 'cincin'.

\section{METODOLOGI PENELITIAN}

Penelitiann ini tidak sekadar melanjutkan dari sebuah penelitian sebelumnya tetapi juga melihat permasalahan-permasalahan yang ada di Dinas Kebudayaan dan Pariwisata Kabupaten Indramayu dan juga permasalahan-permasalahan yang ada di sekolah-sekolah. Untuk itu perlu adanya suatu pelatihan drama tarling untuk menanggulangi permasalahan-permasalahan tersebut. Adapun metode pada penelitian ini adalah observasi, dokumentasi, sosialisasi, pelatihan, diskusi, dan monitoring. Beberapa hal yang akan dilakukan dalam program pengabdian kepada masyarakat ini antara lain:

\section{1) Observasi}

Pada tahap ini yaitu melakukan observasi dengan cara menyebarkan angket ke

siswa-siswa SMA kaitan dengan

keterampilan siswa dalam bermain drama.

2) Dokumentasi

Pada tahap ini yaitu melakukan dokumentasi hasil observasi yang dilakukan pada taham sebelumnya.

3) Sosialisasi

Pada tahap ini yaitu melakukan sosialisasi mengenai drama tarling ke sekolah-sekolah SMA, memperkenalkan lebih jauh lagi seni budaya Indramayu, dan memperkenalkan juga peran Dinas Kebudayaan dan Parisiwata Kabupaten Indramayu.

4) Pelatihan

Pada tahap ini yaitu melakukan pelatihan pada siswa-siswa SMA di Kabupaten Indramayu bertempat di Dinas Kebudayaan dan Parisiwata Kabupaten Indramayu dengan memanfaatkan beberapa fasilitas alat-alat musik tarling. Pelatihan ini melalui beberapa tahap. Di antaranya adalah sebagai berikut: a) menganalisis struktur naskah drama tarling meliputi analisis tema, penokohan, dan alur, b) memilih pemain yang didasarkan pada tingkat intelektual aktor dalam menghafal naskah, improvisasi, kreativitas, dan imajinasi atas peran yang dimainkan, c) melatih pemain/aktor (tubuh, suara, gerak, improvisasi, kreativitas dan imajinasi), 

dari mulai pelatihan MALING (Drama

seperti tim artistik panggung, lighting, musik, tata rias wajah, dan kostum, e) merancang pementasan drama tarling yang menarik, berkualitas, dan layak untuk ditonton.

5) Diskusi

Pada tahap ini yaitu diskusi mengenai rancangan pementasan yang akan dimasukkan sebagai salah satu program Dinas Kebudayaan dan Pariwisata Kabupaten Indramayu yaitu malam pementasan di Kuliner Tjimanoek yang rutin dipentaskan setiap minggu.

6) Monitoring

Pada tahap ini yaitu monitoring konsistensi berjalannya suatu program
Tarling) sampai pada pementasan.

\section{PENELITIAN DAN PEMBAHASAN}

Data hasil angket yang diperoleh melalui jawaban dari 30 responden menunjukan bahwa minat dan keterampilan siswa SMA dalam bermain drama yaitu 0 siswa dalam katagori sangat kurang, 0 siswa dalam katagori kurang, 6 mahasiswa dalam katagori cukup, 24 siswa dalam katagori baik, dan 0 siswa dalam katagori sangat baik. Hal tersebut dapat dilihat melalui tabel berikut.

Tabel 4.1

Hasil Angket Awal Minat dan Keterampilan Siswa SMA dalam Bermain Drama

\begin{tabular}{|c|l|c|c|c|c|c|c|l|}
\hline No & Nama Responden & Pengetahuan & Minat & Apresiasi & Sikap & Harapan & Total & Katagori \\
\hline 1 & Responden 1 & 10 & 10 & 10 & 10 & 10 & 50 & Baik \\
\hline 2 & Responden 2 & 10 & 9 & 10 & 8 & 10 & 47 & Cukup \\
\hline 3 & Responden 3 & 11 & 9 & 12 & 9 & 11 & 52 & Baik \\
\hline 4 & Responden 4 & 10 & 10 & 12 & 12 & 10 & 54 & Baik \\
\hline 5 & Responden 5 & 12 & 11 & 12 & 10 & 11 & 56 & Baik \\
\hline 6 & Responden 6 & 11 & 9 & 6 & 10 & 10 & 49 & Baik \\
\hline 7 & Responden 7 & 10 & 10 & 12 & 10 & 11 & 53 & Baik \\
\hline 8 & Responden 8 & 11 & 9 & 10 & 10 & 11 & 51 & Baik \\
\hline 9 & Responden 9 & 11 & 11 & 12 & 11 & 11 & 56 & Baik \\
\hline 10 & Responden 10 & 12 & 11 & 12 & 10 & 11 & 56 & Baik \\
\hline 11 & Responden 11 & 10 & 10 & 12 & 10 & 11 & 53 & Baik \\
\hline
\end{tabular}




\begin{tabular}{|c|c|c|c|c|c|c|c|c|}
\hline \multicolumn{5}{|c|}{$\begin{array}{l}\text { BAHTERA INDONESIA: } \\
\text { Jurnal Penelitian Pendidikan Bahasa dan Sastra Indonesia }\end{array}$} & \multicolumn{4}{|c|}{$\begin{array}{l}\text { ISSN 2541-3252 } \\
\text { Vol. 5, No. } 2 \text { Sep. } 2020\end{array}$} \\
\hline 12 & Responden 12 & 11 & 8 & 7 & 7 & 10 & 43 & Cukup \\
\hline 13 & Responden 13 & 13 & 9 & 9 & 10 & 11 & 49 & Baik \\
\hline 14 & Responden 14 & 10 & 9 & 7 & 8 & 8 & 47 & Cukup \\
\hline 15 & Responden 15 & 12 & 8 & 11 & 12 & 7 & 50 & Baik \\
\hline 16 & Responden 16 & 9 & 10 & 11 & 9 & 11 & 50 & Baik \\
\hline 17 & Responden 17 & 10 & 12 & 8 & 8 & 9 & 46 & Cukup \\
\hline 18 & Responden 18 & 10 & 12 & 10 & 10 & 9 & 46 & Cukup \\
\hline 19 & Responden 19 & 12 & 11 & 12 & 8 & 12 & 56 & Baik \\
\hline 20 & Responden 20 & 11 & 11 & 12 & 10 & 11 & 55 & Baik \\
\hline 21 & Responden 21 & 11 & 11 & 10 & 10 & 9 & 51 & Baik \\
\hline 22 & Responden 22 & 12 & 11 & 10 & 10 & 8 & 51 & Baik \\
\hline 23 & Responden 23 & 11 & 10 & 12 & 10 & 11 & 54 & Baik \\
\hline 24 & Responden 24 & 11 & 10 & 7 & 9 & 9 & 46 & Cukup \\
\hline 25 & Responden 25 & 10 & 9 & 10 & 11 & 11 & 51 & Baik \\
\hline 26 & Responden 26 & 11 & 9 & 11 & 8 & 9 & 48 & Baik \\
\hline 27 & Responden 27 & 11 & 10 & 10 & 11 & 10 & 52 & Baik \\
\hline 28 & Responden 28 & 13 & 9 & 10 & 10 & 12 & 54 & Baik \\
\hline 29 & Responden 29 & 12 & 10 & 10 & 10 & 11 & 53 & Baik \\
\hline 30 & Responden 30 & 13 & 9 & 10 & 10 & 12 & 54 & Baik \\
\hline \multicolumn{2}{|c|}{ Jumlah } & 331 & 297 & 307 & 291 & 286 & & \\
\hline
\end{tabular}

Berdasarkan tabel tersebut menunjukan bahwa aspek pengetahuan dengan nilai 331 kategori baik, aspek minat dengan nilai 297 kategori baik, aspek apresiasi dengan nilai 307 kategori baik, aspek sikap dengan nilai 291 kategori baik, dan yang terakhir aspek harapan dengan nilai 286 kategori baik.

\section{Pelatihan MALING (Drama Tarling)}

Setelah penyebaran angket awal dilakukan, kemudian peneliti melakukan soasialisasi mengenai pelatihan MALING

(Drama Tarling) dan membuka pendaftaran MALING melalui link. Peserta yang mengikuti pelatihan sejumlah 30 siswa SMA se-Indramayu. Pelatihan MALING (Drama Tarling) dalam penelitian ini meliputi olah tubuh, olah mimik, olah suara, dan olah imajinasi.

\section{Olah Tubuh}

Menurut Bolesavsky R. dalam Harymawan (1993: 30-31), olah tubuh 
ISSN 2541-3252

Vol. 5, No.2, Sep. 2020
BAHTERA INDONESIA:

Jurnal Penelitian Pendidikan Bahasa dan Sastra Indonesia

atau latihan tubuh baik dilakukan satu dalam bentuk yang bermacam-macam: setengah jam sehari. Subjek-subjeknya kata-kata, bunyi, gerak, postur, dan meliputi: (1) senam irama, (2) tari klasik infleksi (perubahan nada suara). dan pengutaran, (3) main anggar, (4) berbagai jenis latihan berapas, (5) latihan menempatkan suara, diksi, bernyanyi, (6) pantomim, (7) tata rias. Impuls, perasaan, atau reaksi yang kita miliki menimbulkan Umumnya, setiap tanda eksternal dari perasaan dan pikiran dapat disebut gestur. Demikian Sitorus (2002: 78) menyebut gestur sebagai hasil dari bentuk olah tubuh atau latihan tubuh.

energi dari dalam diri yang selanjutnya mengalir keluar, mencapai dunia luar

Gambar 4.2.1

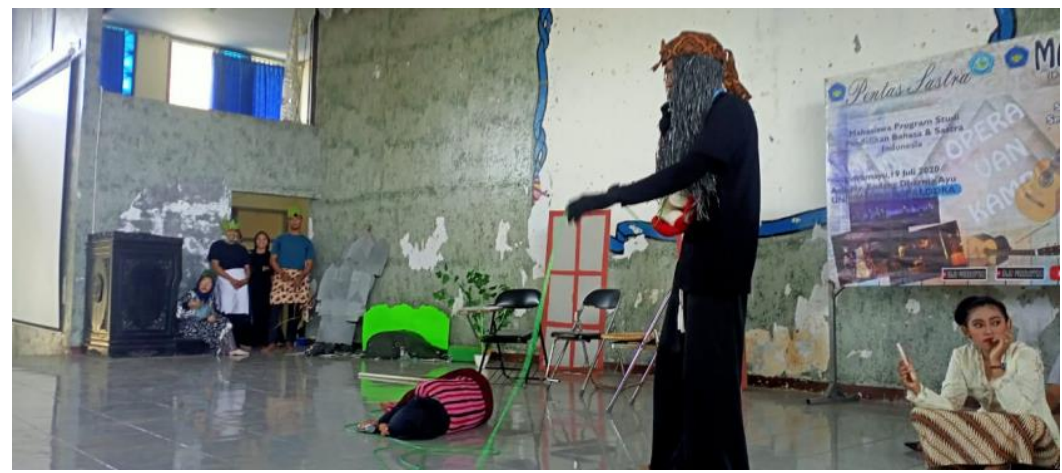

Olah tubuh juga diperlukan dalam bermain drama tarling meskipun kebutuhannya tidak seperti bermain teater dan pantomim. Seperti yang kita ketahui penyampaian pesan dalam teater dan pantomin sebagian besar disampaikan oleh gerak tubuh. Namun, pada adeganadegan tertentu, drama tarling juga membutuhkan olah tubuh yang baik sehingga menunjang peran yang dibawakan. Contohnya pada gambar $4.1 \mathrm{di}$ atas saat pelatihan MALING (Drama Tarling) diambil adegan yang memperlihatkan salah satu pemain jatuh pingsan. Tentunya gerak tubuh yang baik harus benar-benar memperlihatkan ketika menjatuhkan badan untuk pingsan bukan untuk sekadar tidur.

\section{Olah Mimik}

Perangkat wajah dan sekitarnya, menjadi titik sentral yang akan dilatih. Dalam olah mimik ini, kita akan memaksimalkan delikan mata, kerutan dahi, gerakan mulut, pipi, rahang, leher kepala, secara berkesinambungan. Mimik merupakan sebuah ekspresi, dan mata merupakan pusat ekspresi. Perasaan marah, cinta, dan lain-lain akan terpancar lewat mata. Ekspresi sangatlah menentukan permainan seorang aktor. 


\section{BAHTERA INDONESIA:}

Jurnal Penelitian Pendidikan Bahasa dan Sastra Indonesia
ISSN 2541-3252

Vol. 5, No. 2 Sep. 2020
Meskipun bermacam gerakan sudah bagus, suara telah jadi jaminan, dan diksi pun kena, akan kurang meyakinkan ketika ekspresi matanya kosong dan berimbas pada dialog yang akan kurang meyakinkan penonton, sehingga permainannya akan terasa hambar. Diksi merupakan esensi penulisan puisi yang merupakan faktor penentu kemampuan daya cipta. Penempatan kata-kata sangat penting artinya dalam rangka menumbuhkan suasana puitik yang akan membawa pembaca pada penikmatan dan pemahaman yang menyeluruh atau total
(Suminto A. Sayuti, 2008:143-144).

Tubuh yang lentur dengan stamina yang tinggi akan membuat seorang pendekar silat mampu berkelit dan sekaligus menyerang pada kondisi yang sulit sekalipun. Itu semua berkat keterlatihan seluruh organ tubuh yang ia dapatkan dengan susah payah dalam latihan jurusjurus sekian lamanya. Demikian juga seorang pemeran akan membawakan laku peranannya dengan baik seolah tidak ada beban teknis sebab ia dengan kesadaran yang penuh telah melatih seluruh peralatan pemeranannya.

\section{Gambar 4.2.2}

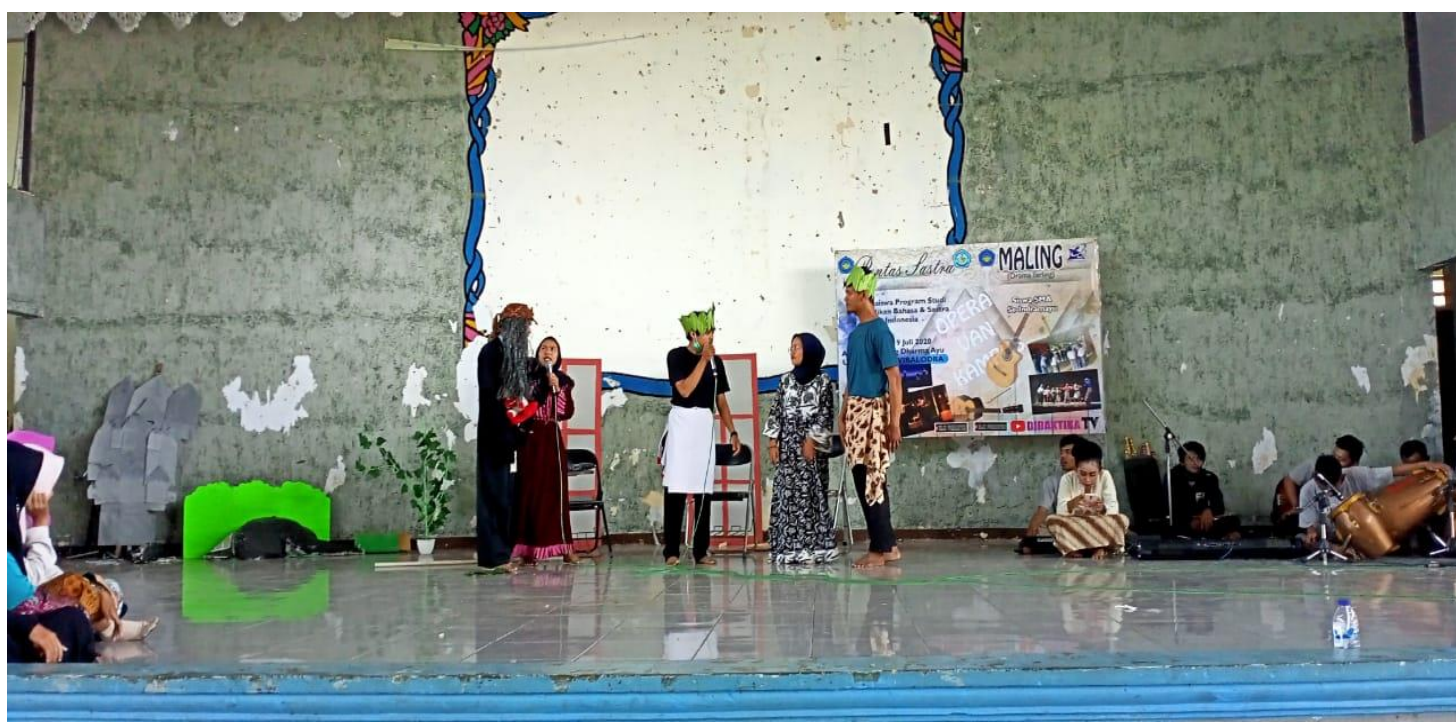

Cerita drama tarling biasanya mengangkat tema pada kehidupan seharihari di masyarakat khususnya masyarakat sekitar Indramayu-Cirebon. Olah mimik (ekpresi) bisa dengan mudah dilakukan oleh pemain karena cerita yang dibawakan sebagian besar sudah dipahami oleh pemain. Namun, hal ini akan menjadi kesulitan bagi pemain yang memiliki perbedaan jauh antara peran pada cerita 
ISSN 2541-3252

Vol. 5, No.2, Sep. 2020
BAHTERA INDONESIA:

Jurnal Penelitian Pendidikan Bahasa dan Sastra Indonesia dengan kehidupan nyata. Contohnya pada

gambar 4.2 di atas yang memperlihatkan seorang ayah yang memiliki tiga orang putri yang memiliki watak yang berbedabeda, tentu ekpresi yang diperlihatkan oleh seorang ayah yang pada kehidupan nyatanya jangankan memiliki seorang putri bahkan menikah juga belum pernah, hal ini akan menjadi salah satu kendala dalam mengekspresikan berbagai dialog sebagai seorang ayah.

\section{Olah Suara}

Menurut Herman J. Waluyo (2002: 117), olah vokal atau latihan suara dapat diartikan latihan mengucapkan suara secara jelas dan nyaring, dapat juga berarti latihan penjiwaan suara. Warna suara bagaimana yang tepat, harus disesuaikan dengan watak peran, umur peran, dan keadaan peran sosial itu. Nada suara juga harus diatur, agar membantu membedakan peran yang satu dengan peran yang lain. Secara lebih detail, aksen orang-orang yang berasal dari daerah tertentu, perlu juga diwujudkan dalam latihan suara ini. Yang harus mendapatkan perhatian seksama, adalah suara itu hendaklah jelas, nyaring, mudah ditangkap, komunikatif, dan diucapkan sesuai daerah artikulasinya.

Suara sebagai salah satu media pengungkapan ekspresi pemeran. Dalam hal ini media penyampai informasi melalui dialog. Informasi mencakup tentang alur cerita, kejadian, watak, peran, sikap emosi peran, kondisi serta usia peran, dan lain-lain, hendaknya tersampaikan secara jelas melalui keterampilan pemeran dalam melontarkan dialog. (Catur J. Wibisono, 1999: 3) Selanjutnya Wibisono mengemukakan, bahwa olah vokal merupakan salah satu teknik produksi suara yang berhubungan erat dengan pengolahan alat-alat produksi suara dan pembentukkan suara. Hal ini mencakup pernapasan, fonasi, gema suara (resonansi), pengucapan (artikulasi), dan proyeksi. Penguasaan suara dalam seni acting pada dasarnya adalah penguasaan diri secara utuh, karena kedudukan suara dalam hal ini hanyalah merupakan salah satu alat ekspresi dan totalitas diri kita sebagai seorang pemain (aktor). Pengertian 'penguasaan diti secara utuh' menuntut suatu keseimbangan seluruh aspek serta alat-alatnya, baik yang menyangkut kegiatan indrawi, perasaan, pikiran atau yang bisa disebut segi-segi dalam dari seni acting, maupun yang menyangkut segi-segi luarnya seperti tubuh dan suara. Ketimpangan akan menghasilkan ketimpangan.

\section{Gambar 4.2.3}




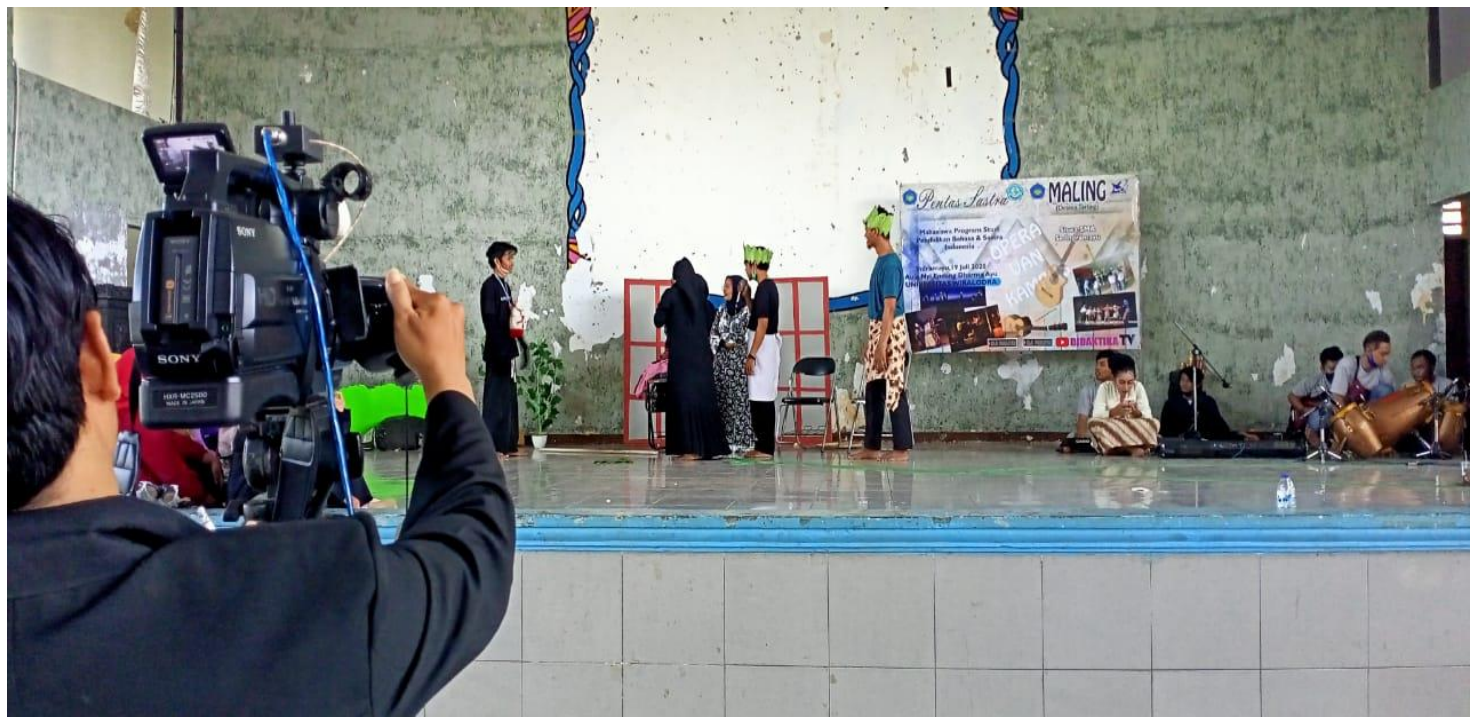

Drama taling (gitar dan suling) tentunya menyuguhkan cerita yang tidak akan terlepas dari musik yaitu gitar dan suling. Hal ini akan mengharuskan pemain menggunakan alat bantu yaitu microphone. Penggunaan microphone yang tidak baik akan mengganggu ekpresi dari pemain. Oleh karena itu diperlukan olah suara yang baik dalam penggunaan microphone sehingga tidak akan menjadi kendala ketika sedang berdialog dan bernyanyi dengan diiringi musik gitar dan suling.

\section{Olah Imajinasi}

Imajinasi adalah suatu cara bagi seorang aktor untuk mendekati pikiran dan perasaan karakte yang akan dimainkan sehingga dia dapat menempatkan dirinya dalam situasi si karakter. Metode ini merupakan proses imajinasi dimana di aktor melakukan identifikasi dengan karakter tokohnya. Di setiap identifikasi dengan karakter tokohnya, si aktor harus melihat pengalaman hidupnya dan pengalaman hidup yang paling relevan untuk ditransver ke pengalaman hidup yang dimiliki si karakter. Si aktor harus mampu menyelidiki asal mula dirinya sendiri untuk dapat tulus dan jujur pada realita eksistensi dirinya yang baru. Imajinasi menciptakan hal-hal yang mungkin ada atau mungkin terjadi, sedangkan fantasi membuat hal-hal yang tidak ada, yan tidak pernah ada. Tapi siapa tahu, suatu hari kesemuanya itu mungkin ada. Bagi seorang aktor, proses kreatif ini dipimpin oleh imajinasinya. 


\section{Gambar 4.2.4}

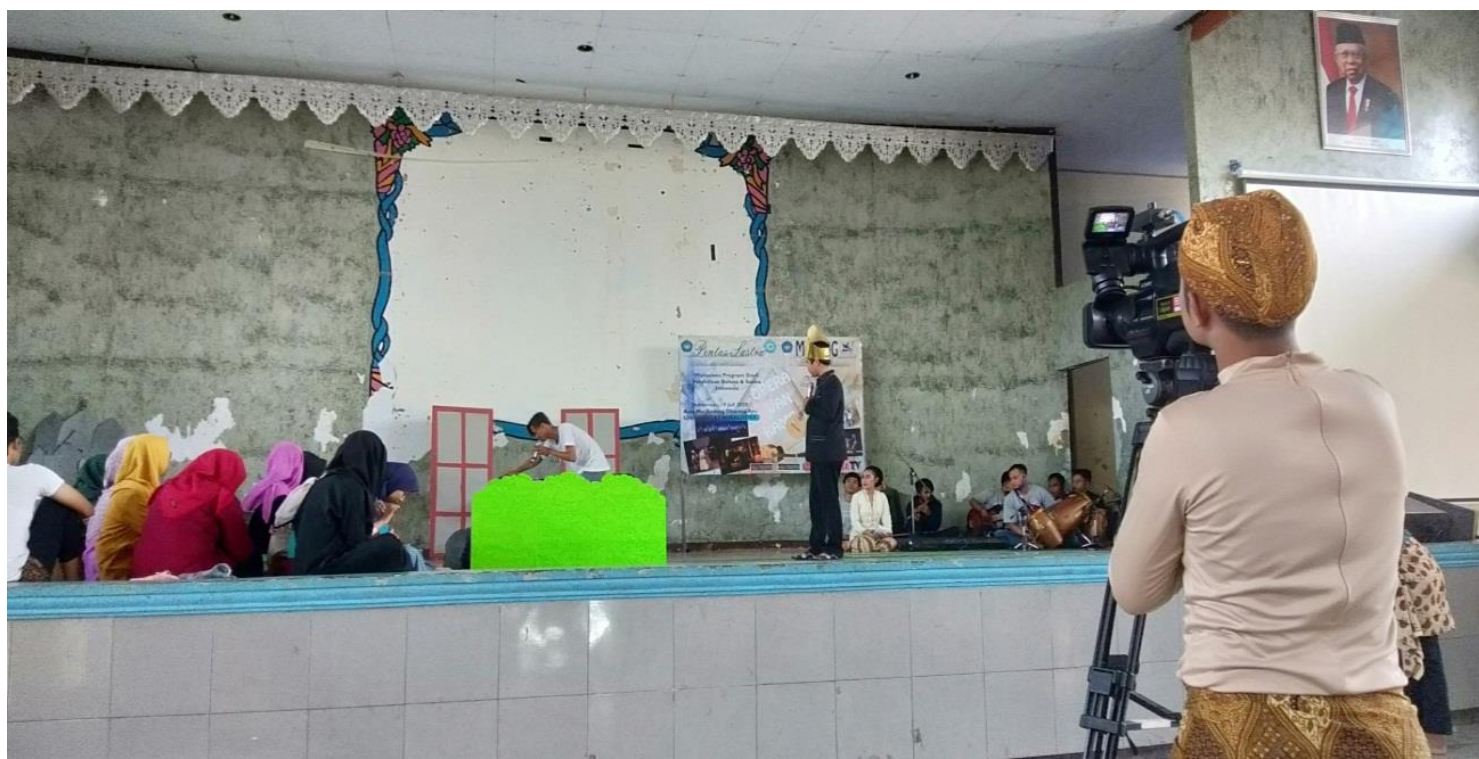

Drama tarling yang biasa dipentaskan biasanya menampilkan tata panggung yang sangat biasa tanpa ada properti lain yang mendukung cerita. Sehingga olah imajinasi sangatlah diperlukan. Contoh pada gambar 3.4 di atas ketika seseorang bertamu ke rumah, harus bisa mengimajinasikan posisi pintu rumah sehingga ketika perperan olah tubuh pemain menggambarkan imajinasinya masuk ke rumah melalui pintu rumah meskipun di atas panggung tidak terlihat adanya pintu.

\section{Hasil Angket Akhir Minat dan}

\section{Keterampilan Siswa SMA dalam}

\section{Bermain Drama}

Data hasil angket akhir yang diperoleh melalui jawaban dari 30 responden menunjukan bahwa minat dan keterampilan siswa SMA dalam bermain drama yaitu 0 siswa dalam katagori sangat kurang, 0 siswa dalam katagori kurang, 0 mahasiswa dalam katagori cukup, 5 siswa dalam katagori baik, dan 25 siswa dalam katagori sangat baik. Hal tersebut dapat dilihat melalui tabel berikut.

Tabel 4.3

\section{Hasil Angket Akhir Minat dan Keterampilan Siswa SMA dalam Bermain Drama}

\begin{tabular}{|c|l|c|c|c|c|c|c|l|}
\hline No & Nama Responden & Pengetahuan & Minat & Apresiasi & Sikap & Harapan & Total & Keterangan \\
\hline 1 & Responden 1 & 15 & 13 & 15 & 13 & 16 & 72 & Sangat Baik \\
\hline
\end{tabular}


BAHTERA INDONESIA:

ISSN 2541-3252

Jurnal Penelitian Pendidikan Bahasa dan Sastra Indonesia

Vol. 5, No. 2 Sep. 2020

\begin{tabular}{|c|c|c|c|c|c|c|c|c|}
\hline 2 & Responden 2 & 15 & 14 & 13 & 15 & 14 & 72 & Sangat Baik \\
\hline 3 & Responden 3 & 14 & 12 & 14 & 12 & 14 & 66 & Sangat Baik \\
\hline 4 & Responden 4 & 16 & 14 & 16 & 14 & 15 & 75 & Sangat Baik \\
\hline 5 & Responden 5 & 15 & 13 & 16 & 16 & 16 & 76 & Sangat Baik \\
\hline 6 & Responden 6 & 15 & 16 & 15 & 15 & 16 & 77 & Sangat Baik \\
\hline 7 & Responden 7 & 12 & 12 & 12 & 12 & 12 & 60 & Baik \\
\hline 8 & Responden 8 & 14 & 13 & 14 & 13 & 13 & 67 & Sangat Baik \\
\hline 9 & Responden 9 & 14 & 12 & 12 & 13 & 12 & 63 & Baik \\
\hline 10 & Responden 10 & 16 & 15 & 16 & 13 & 15 & 75 & Sangat Baik \\
\hline 11 & Responden 11 & 15 & 15 & 16 & 14 & 15 & 75 & Sangat Baik \\
\hline 12 & Responden 12 & 14 & 14 & 15 & 15 & 14 & 76 & Sangat Baik \\
\hline 13 & Responden 13 & 13 & 14 & 14 & 14 & 14 & 69 & Sangat Baik \\
\hline 14 & Responden 14 & 15 & 13 & 16 & 14 & 15 & 73 & Sangat Baik \\
\hline 15 & Responden 15 & 14 & 14 & 13 & 12 & 14 & 67 & Sangat Baik \\
\hline 16 & Responden 16 & 13 & 14 & 12 & 13 & 16 & 68 & Sangat Baik \\
\hline 17 & Responden 17 & 12 & 12 & 12 & 14 & 13 & 63 & Baik \\
\hline 18 & Responden 18 & 12 & 12 & 12 & 13 & 13 & 62 & Baik \\
\hline 19 & Responden 19 & 12 & 13 & 13 & 12 & 15 & 65 & Sangat Baik \\
\hline 20 & Responden 20 & 12 & 13 & 12 & 13 & 14 & 64 & Sangat Baik \\
\hline 21 & Responden 21 & 15 & 14 & 14 & 14 & 16 & 69 & Sangat Baik \\
\hline 22 & Responden 22 & 15 & 14 & 16 & 14 & 15 & 74 & Sangat Baik \\
\hline 23 & Responden 23 & 14 & 14 & 16 & 14 & 15 & 73 & Sangat Baik \\
\hline 24 & Responden 24 & 15 & 14 & 15 & 14 & 15 & 73 & Sangat Baik \\
\hline 25 & Responden 25 & 15 & 14 & 12 & 15 & 15 & 70 & Sangat Baik \\
\hline 26 & Responden 26 & 15 & 14 & 12 & 15 & 13 & 69 & Sangat Baik \\
\hline 27 & Responden 27 & 15 & 16 & 14 & 15 & 15 & 75 & Sangat Baik \\
\hline 28 & Responden 28 & 15 & 14 & 15 & 14 & 16 & 74 & Sangat Baik \\
\hline 29 & Responden 29 & 14 & 11 & 12 & 13 & 12 & 62 & Baik \\
\hline 30 & Responden 30 & 14 & 14 & 15 & 14 & 16 & 74 & Sangat Baik \\
\hline \multicolumn{2}{|c|}{ Jumlah } & 425 & 407 & 419 & 412 & 434 & & \\
\hline
\end{tabular}

Berdasarkan tabel tersebut dengan nilai 425 kategori sangat baik, menunjukan bahwa aspek pengetahuan aspek minat dengan nilai 407 kategori 
419 kategori sangat baik, aspek sikap dengan nilai 412 kategori sangat baik, dan yang terakhir aspek harapan dengan nilai 434 kategori sangat baik. Jika dibandingkan antara angket awal dan

\section{DAFTAR PUSTAKA}

Arikunto, Suharsimi. 2006. Prosedur Penelitian, Suatu Pendekatan Praktek. Jakarta : Rineka

Cipta.

Cohen. 1999. "The incantation of semar smiles: A tarling musical drama by Pepen Effendi”.

Depdikbud. 2006. Kurikulum Tingkat Satuan Pendidikan Mata Pelajaran Bahasa dan Sastra

Indonesia SLTP.Jakarta :

Depdikbud.

Faruk, H.T. 2007.“Liminalitas dan Pengalaman Pascamodern". Cirebon: Kongres Bahasa Cirebon 1, 31 Juli-2 Agustus.

Harymawan, R. M. $\quad$ A. 1988. Dramaturgi. Bandung: CV Rosda.

Hasanudin. 2009. Drama Karya dalam Dua Dimensi. Bandung: Angkasa.

Hidayatullah, Riyan. 2015. "Seni Tarling dan Perkembangannya di Cirebon". FKIP Universitas lampung. Volume 1 Nomor 1, Juni 2015.

Kasim, Supali. 2002. "Migrasi Bunyi dari Gamelan ke Gitar Suling
(Tarling)". Indramayu: Dewan Kesenian Indramayu.

Lexy J. Moleong. 2005. Metodologi Penelitian Kualitatif. Bandung: Rosdakarya.

Makmun, Syamsudin, Abin. 2004. Psikologi Pendidikan. Bandung: Rosda.

Nuryanto. 2014. Mari Bermain Drama (Kebahagiaan Sejati) Panduan Praktis Untuk Menjadi Aktor \& Aktris).Cirebon: Syariah Nurjati Press.

Riantiarno, N. 2011 Kitab Teater: Tanya Jawab Seputar Seni Pertunjukan. Jakarta: Gramedia Widia Sarana Indonesia,

Salam, Chaerul. 2014. Tesis: Perlawanan Wanita terhadap Dominasi Partiarki dalam Teks Tarling Cirebon: Sebuah Analisis Semiotik Riffatere. Yogyakarta: Pascasarjana FIlsafat UGM.

Salim. 2015. “ Perkembangan dan Eksistensi Musik Tarling Cirebon. Jurnal of Arts Aducation.

http://journal.unnes.ac.id/sju/in deks.php/catharsi diakses pada 20 Maret 2018.

Santosa, Puji. 2010. "Kearifan Budaya Lokal Sastra Lisan Kafoa". Jakarta: Badan Bahasa. 
BAHTERA INDONESIA:

Jurnal Penelitian Pendidikan Bahasa dan Sastra Indonesia

Saptono, Hariadi (ed). 2013. Warisan

Budaya Wangsa Cerbon-

Dermayu. Jakarta: Bentara

Budaya.

Sugiyono. 2013. Metode Penelitian

Pendidikan (Pendekatan

Kualitatif, Kuantitatif, dan

$R \& D)$. Bandung: Alfabeta.

Sulistiji, dkk, 2001.Kamus Basa Indramayu. Indramayu: Dinas Pendidikan dan Kebudayaan Kabupaten Indramayu.

Sumardjo, Jakob. 2011. Pola Rasionalitas Budaya.

Bandung: Kelir.

Supriatna, Adi dkk. 2016. "Upaya Pelestarian Musik Tarling Cirebon Studi Kasus pada Group Tarling Putra Sangkala Pimpinan Bapak Askadi". Thesis: Fakultas Seni dan Sastra.

Suratno, Siti Chamamah dan Chairul Salam. 2005. "Perlawanan Wanita Terhadap Dominasi Patriarki dalam Teks Tarling Cirebon: Sebuah Analisis Semiotik Riffatere. Yogyakarta: Humanika, 18/2, April 2020.

Suroso. 2015. Drama Teori dan Praktik Pementasan. Yogyakarta: Almatera.

Waluyo, Herman J. 2001. Drama Teori dan Pengajarannya. Yogyakarta: Hanindita Graha Widya.

Waluyo. 2006. Drama : Naskah, Pementasan, dan Pengajarannya.

Cetakan 1. Surakarta: LPP, UNS Press. 